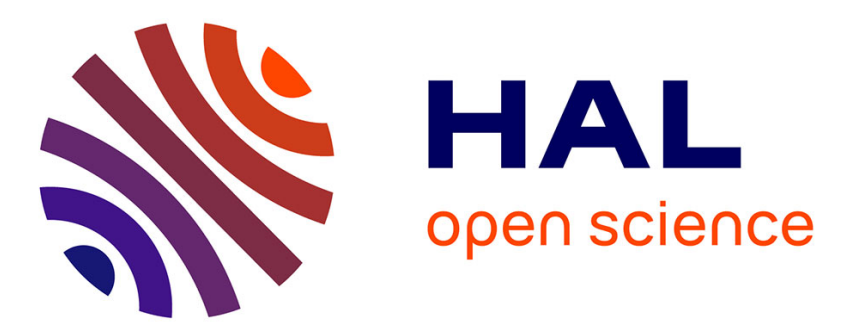

\title{
Contribution to the knowledge of ticks (Acarina: Ixodidae) in Gabon
}

\author{
X. Pourrut, K.A. Emane, J.-L. Camicas, E. Leroy, J.P. Gonzalez
}

\section{To cite this version:}

X. Pourrut, K.A. Emane, J.-L. Camicas, E. Leroy, J.P. Gonzalez. Contribution to the knowledge of ticks (Acarina: Ixodidae) in Gabon. Acarologia, 2011, 51 (4), pp.465-471. 10.1051/acarologia/20112028. hal-01600443

\section{HAL Id: hal-01600443 \\ https://hal.science/hal-01600443}

Submitted on 2 Oct 2017

HAL is a multi-disciplinary open access archive for the deposit and dissemination of scientific research documents, whether they are published or not. The documents may come from teaching and research institutions in France or abroad, or from public or private research centers.
L'archive ouverte pluridisciplinaire HAL, est destinée au dépôt et à la diffusion de documents scientifiques de niveau recherche, publiés ou non, émanant des établissements d'enseignement et de recherche français ou étrangers, des laboratoires publics ou privés.

\section{(ㅇ)(1) $\$$}

Distributed under a Creative Commons Attribution - NonCommercial - NoDerivatives| 4.0 


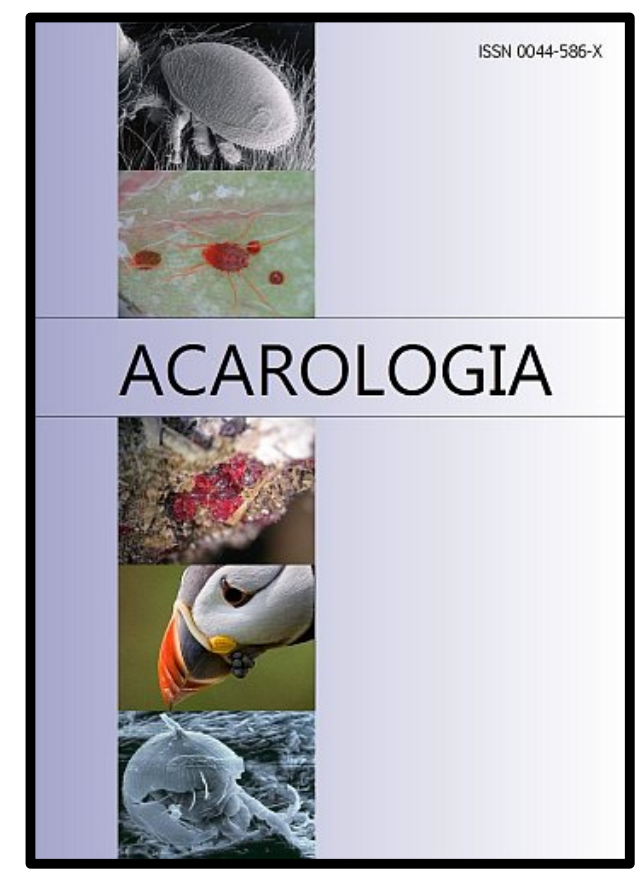

\section{ACAROLOGIA}

A quarterly journal of acarology, since 1959

Publishing on all aspects of the Acari

All information:

http://www1.montpellier.inra.fr/CBGP/acarologia/ acarologia@supagro.inra.fr

\section{OPEN ACCESS}

\section{Acarologia is proudly non-profit, with no page charges and free open access}

Please help us maintain this system by encouraging your institutes to subscribe to the print version of the journal and by sending us your high quality research on the Acari.

Subscriptions: Year 2017 (Volume 57): $380 €$ http://www1.montpellier.inra.fr/CBGP/acarologia/subscribe.php

Previous volumes (2010-2015): $250 € /$ year (4 issues)

Acarologia, CBGP, CS 30016, 34988 MONTFERRIER-sur-LEZ Cedex, France

The digitalization of Acarologia papers prior to 2000 was supported by Agropolis Fondation under the reference ID 1500-024 through the « Investissements d'avenir » programme

(Labex Agro: ANR-10-LABX-0001-01)
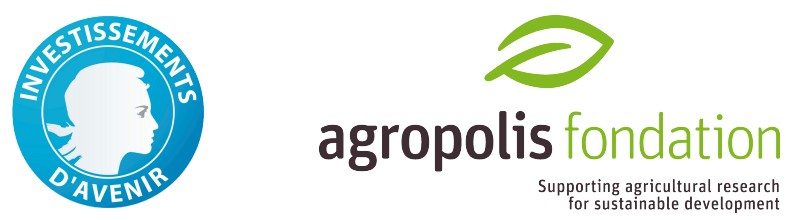

Acarologia is under free license and distributed under the terms of the

Creative Commons-BY-NC-ND which permits unrestricted non-commercial use, distribution, and reproduction in any medium, provided the original author and source are credited. 


\title{
CONTRIBUTION TO THE KNOWLEDGE OF TICKS (ACARINA: IXODIDAE)
}

IN GABON

\author{
Xavier Pourrut ${ }^{1,2}$, Kevin A. EMANE ${ }^{2}$, Jean-Louis CAMICAS ${ }^{1}$, Eric LEROY ${ }^{1,2}$ \\ and Jean-Paul GONZALEZ ${ }^{2}$
}

(Received 26 September 2011; accepted 29 November 2011; published online 20 December 2011)

${ }^{1}$ Institut de Recherche pour le Développement, Mivegec, Montpellier, France. Xavier.pourrut@ird.fr (Corresponding author); jean-louis.camicas@ird.fr; eric.leroy@ird.fr

${ }^{2}$ Centre International de Recherches Médicales, Franceville, Gabon. allein2@live.fr; jean-paul.gonzalez@ird.fr

\begin{abstract}
Few data are available on the distribution of tick species in Gabon. We report the results of a survey of ticks collected from wild and domestic animals, and in the environment, in several regions of Gabon. We identified four tick species for the first time in Gabon, namely Haemaphysalis paralaechi, Ixodes aulacodi, Rhipicephalus annulatus and Rhipicephalus simpsoni and we report 28 tick species for this country.
\end{abstract}

KEYWORDS - tick; Ixodidae; Gabon; distribution; bushmeat

\section{INTRODUCTION}

Several authors have studied the distribution of tick species in Africa (Arthur 1965; Elbl and Anastos 1966a; 1966b; 1966c; 1966d; Hoogstraal 1956; Morel 1965b; Morel 1969; Robinson 1926; Walker et al. 2000), especially in Cameroon (Morel and Mouchet 1958; 1965) and the Central African Republic (Cornet 1995).

However, the data are far from complete for most parts of central Africa. We therefore conducted a survey of specimens collected in several regions of Gabon, and updated the list of ticks (Acarida, Ixodidae) in this country.

\section{MATERIALS AND METHODS}

Sampling took place from October 2009 to December 2010. Ticks were collected by direct examination of animals and by the sledge method in the environment (Cornet et al. 1984). Wild animals were those captured by hunters for trade and consumption as bushmeat in villages. Domestic animals were freeroaming in villages. On bushmeat animals, ticks were collected within 12 to 72 hours after death. All specimens were preserved in $75 \%$ ethanol until examination.

Speciation was based on the key identification method (Arthur 1965; Elbl and Anastos 1966a; 1966b; 1966c; 1966d; Hoogstraal 1956; Morel 1965b; Walker et al. 2000). The references to tick records from old collections (Collection Brumpt, Institut de Parasitologie, Faculté de Médecine de Paris, 1930; 


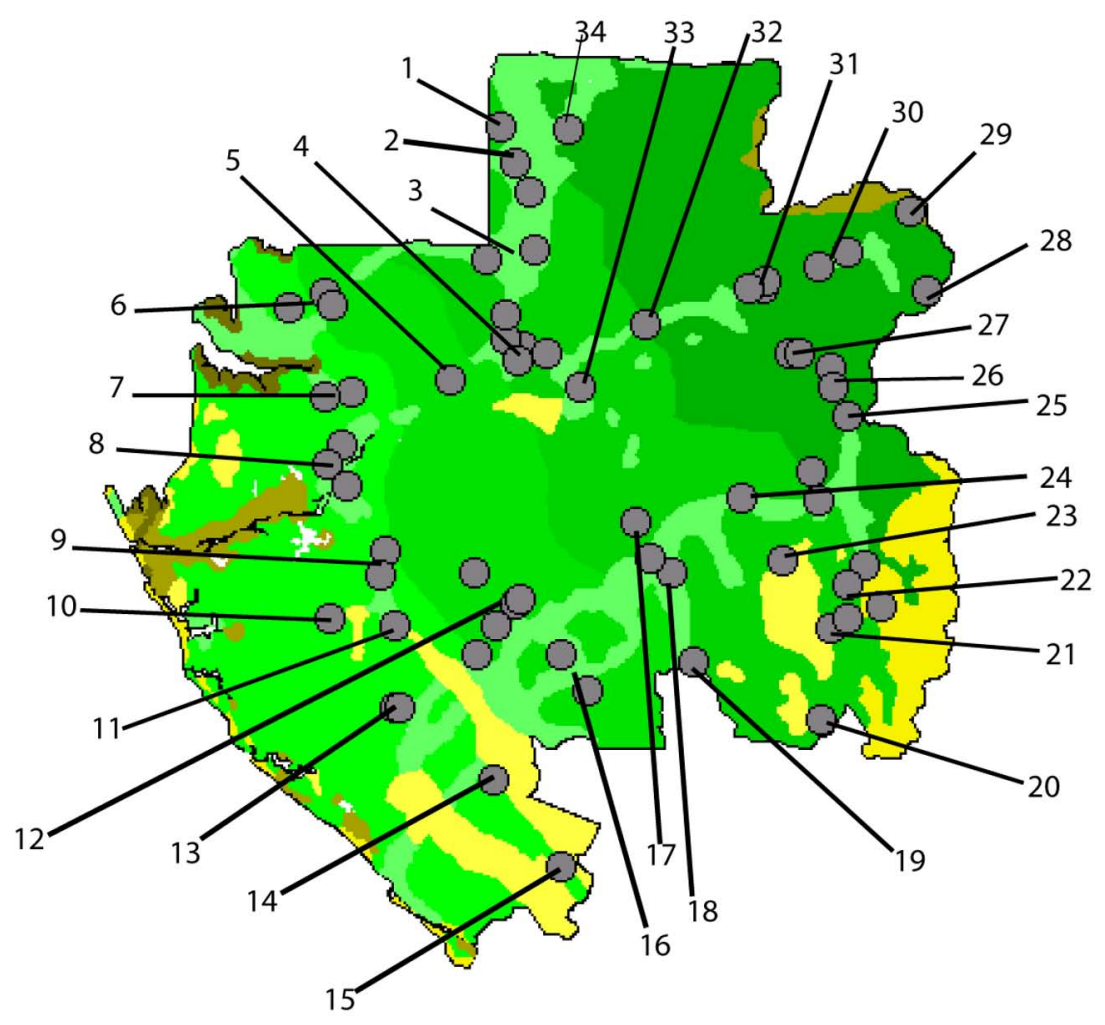

FIGURE 1: Location of the 64 sites (numbered circles) where ticks were sampled in the three main Gabonese ecosystems: forest (green), savannas (yellow) and lakes (brown). 1 - Mbomo; 2 - Oyem, Nkolabona; 3 - Abong Awoum, Akon Ebe; 4 - Zomoko, Trouwaya, Lalara, Laboka I, Lolo 1; 5 - Mevang; 6 - Lac Nkouvié, Mela, Latta; 7 - Weliga 2, Hevegab; 8 - Lambaréné; Benguié III, Koungoulé; 9 - Mimongo, Mandilou; 10 - Massana; 11 - Guidouma; 12 - Tambi, Mounongou, Boutoumbi, Oyou, Bandi; 13 - Guietsou, Ilendo; 14 - Douvouli; 15 - Bighoundou; 16 - Moloulou, Ongongo; 17 - Baniaty; 18 - Mabimbi, Lemenga; 19 - Dienga; 20 - Doumaï; 21 Franceville, Ondili; 22 - Kassiélé, Omoy, Onkoua; 23 - Olonga; 24 - Baposso, Antsia, Sebe; 25 - Djounou; 26 - Bakwaka, Yoko; 27 - Zolende, Hendje; 28 - Ekata; 29 - Grand itoumbi; 30 - Zambakaganga, Zadouinde; 31 - Massaha, Nze Vatican, La Scierie; 32 Afoumadzo; 33 - Lopé; $34-$ Mba

Muséum Histoire Naturelle Paris, 1910; Institut Pasteur Paris, 1954) were obtained from Morel (1965b). The mammal nomenclature was based on Wilson and Reeder (2005).

\section{RESULTS}

\section{Collection sites}

Ticks were collected at 64 sites distributed throughout Gabon (Figure 1), as follows: Abong Awoum $\left(0^{\circ} 58^{\prime} \mathrm{N}, 11^{\circ} 37^{\prime} \mathrm{E}\right)$; Afoumadzo $\left(0^{\circ} 27^{\prime} \mathrm{N}, 12^{\circ} 23^{\prime} \mathrm{E}\right)$; Akon Ebe $\left(0^{\circ} 54^{\prime} \mathrm{N}, 1^{\circ} 18^{\prime} \mathrm{E}\right) ;$ Antsia $\left(0^{\circ} 34^{\prime} \mathrm{S}\right.$, $\left.13^{\circ} 50^{\prime} \mathrm{N}\right)$; Bakwaka $\left(0^{\circ} 9^{\prime} \mathrm{N}, 13^{\circ} 38^{\prime} \mathrm{E}\right)$; Bandi $\left(1^{\circ} 48^{\prime} \mathrm{S}\right.$, $\left.11^{\circ} 14^{\prime} \mathrm{E}\right)$; Baniaty $\left(0^{\circ} 54^{\prime} \mathrm{S}, 12^{\circ} 19^{\prime} \mathrm{E}\right)$; Baposso $\left(0^{\circ} 44^{\prime} \mathrm{S}\right.$, $\left.13^{\circ} 2^{\prime} \mathrm{E}\right)$; Benguie III $\left(0^{\circ} 23^{\prime} \mathrm{S}, 10^{\circ} 19^{\prime} \mathrm{E}\right)$; Bighoundou $\left(3^{\circ} 15^{\prime} \mathrm{S}, 11^{\circ} 12^{\prime} \mathrm{E}\right)$; Boutoumbi $\left(1^{\circ} 28^{\prime} \mathrm{S}\right.$; $\left.11^{\circ} 49^{\prime} \mathrm{E}\right)$; Dienga $\left(1^{\circ} 52^{\prime} \mathrm{S}, 12^{\circ} 43^{\prime} \mathrm{E}\right)$; Djounou $\left(0^{\circ} 10^{\prime} \mathrm{S}, 13^{\circ} 45^{\prime} \mathrm{E}\right)$; Doumaï $\left(2^{\circ} 14^{\prime} \mathrm{S}, 1^{\circ} 34^{\prime} \mathrm{E}\right)$; Douvouli $\left(2^{\circ} 14^{\prime} \mathrm{S}\right.$, $\left.13^{\circ} 34^{\prime} \mathrm{E}\right)$; Ekata $\left(0^{\circ} 40^{\prime} \mathrm{N}, 14^{\circ} 17^{\prime} \mathrm{E}\right)$; Franceville $\left(1^{\circ} 40^{\prime} \mathrm{S}, 13^{\circ} 31^{\prime} \mathrm{E}\right)$; Grand-itoumbi $\left(1^{\circ} 14^{\prime} \mathrm{N}, 14^{\circ} 11^{\prime} \mathrm{E}\right)$; Guidouma $\left(1^{\circ} 37^{\prime} \mathrm{S}, 10^{\circ} 41^{\prime} \mathrm{E}\right)$; Guietsou $\left(2^{\circ} 10^{\prime} \mathrm{S}\right.$, $\left.10^{\circ} 41^{\prime} \mathrm{E}\right) ; \quad$ Hendje $\left(0^{\circ} 15^{\prime} \mathrm{N}, 13^{\circ} 22^{\prime} \mathrm{E}\right) ; \quad$ Hevegab $\left(0^{\circ} 0^{\prime} 53^{\prime \prime} \mathrm{S}, \quad 10^{\circ} 23^{\prime} \mathrm{E}\right)$; Ilendo $\left(2^{\circ} 10^{\prime} \mathrm{S}, \quad 10^{\circ} 43^{\prime} \mathrm{E}\right)$; Kassiélé $\left(1^{\circ} 12^{\prime} \mathrm{S}, 13^{\circ} 52^{\prime} \mathrm{E}\right) ;$ Koungoulé $\left(0^{\circ} 30^{\prime} \mathrm{S}\right.$, $\left.10^{\circ} 13^{\prime} \mathrm{E}\right)$; La scierie $\left(0^{\circ} 42^{\prime} \mathrm{N}\right.$; $\left.13^{\circ} 05^{\prime} \mathrm{E}\right)$; Laboka I 
$\left(0^{\circ} 18^{\prime} \mathrm{N}, 11^{\circ} 33^{\prime} \mathrm{E}\right) ;$ Lac Nkouvié $\left(0^{\circ} 34^{\prime} \mathrm{N}, 9^{\circ} 57^{\prime} \mathrm{E}\right)$; Lalara $\left(0^{\circ} 21^{\prime} \mathrm{N}, 11^{\circ} 26^{\prime} \mathrm{E}\right)$; Lambéréné $\left(0^{\circ} 40^{\prime} \mathrm{S}\right.$, $\left.10^{\circ} 21^{\prime} \mathrm{E}\right)$; Latta $\left(0^{\circ} 40^{\prime} \mathrm{N}, 10^{\circ} 12^{\prime} \mathrm{E}\right)$; Lemenga $\left(1^{\circ} 25^{\prime} \mathrm{S}\right.$, $\left.12^{\circ} 34^{\prime} \mathrm{E}\right)$; Lolo $1\left(0^{\circ} 16 \mathrm{~N}, 11^{\circ} 42^{\prime} \mathrm{E}\right)$; Lopé $\left(0^{\circ} 1^{\prime} \mathrm{N}\right.$, $\left.11^{\circ} 59^{\prime} \mathrm{E}\right) ; \quad$ Mabimbi $\left(1^{\circ} 9^{\prime} \mathrm{S}, 1^{\circ} 25^{\prime} \mathrm{E}\right)$, Mandilou $\left(1^{\circ} 16^{\prime} \mathrm{S}, 10^{\circ} 35^{\prime} \mathrm{E}\right)$, Massaha $\left(0^{\circ} 42^{\prime} \mathrm{N}, 13^{\circ} 11^{\prime} \mathrm{E}\right)$, Massana $\left(1^{\circ} 34^{\prime} \mathrm{S}, 10^{\circ} 14^{\prime} \mathrm{E}\right), \quad \mathrm{Mba}\left(1^{\circ} 74^{\prime} \mathrm{N}, 1^{\circ} 51^{\prime} \mathrm{E}\right)$, Mbomo $\left(1^{\circ} 48^{\prime} \mathrm{N}, 11^{\circ} 28^{\prime} \mathrm{E}\right)$; Mela $\left(0^{\circ} 35^{\prime} \mathrm{N}, 10^{\circ} 15^{\prime} \mathrm{E}\right)$, Mevang $\left(0^{\circ} 5^{\prime} \mathrm{N}, 11^{\circ} 4^{\prime} \mathrm{E}\right)$; Mimongo $\left(1^{\circ} 6^{\prime} \mathrm{S}, 10^{\circ} 37^{\prime} \mathrm{E}\right)$; Moloulou (1 $\left.1^{\circ} 53^{\prime} \mathrm{S}, 11^{\circ} 49^{\prime} \mathrm{E}\right)$; Mounongou $\left(1^{\circ} 26^{\prime} \mathrm{S}\right.$, $\left.11^{\circ} 52^{\prime} \mathrm{E}\right)$; Nkolabona $\left(1^{\circ} 21^{\prime} \mathrm{N}, 1^{\circ} 59^{\prime} \mathrm{E}\right)$; Nze vatican $\left(0^{\circ} 45^{\prime} \mathrm{N}, 13^{\circ} 19^{\prime} \mathrm{E}\right)$; Olounga $\left(1^{\circ} 10^{\prime} \mathrm{S}, 13^{\circ} 31^{\prime} \mathrm{E}\right)$; Omoy $\left(1^{\circ} 19^{\prime} \mathrm{S}, 13^{\circ} 46^{\prime} \mathrm{E}\right)$; Ondili $\left(1^{\circ} 33^{\prime} \mathrm{S}, 13^{\circ} 46^{\prime} \mathrm{E}\right)$; Ongongo $\left(2^{\circ} 04^{\prime} \mathrm{S}, 11^{\circ} 58^{\prime} \mathrm{E}\right)$, Onkoua $\left(1^{\circ} 47^{\prime} \mathrm{S}, 13^{\circ} 38^{\prime} \mathrm{E}\right)$; Oyem $\left(1^{\circ} 33^{\prime} \mathrm{N}, 11^{\circ} 30^{\prime} \mathrm{E}\right)$; Oyou $\left(1^{\circ} 37^{\prime} \mathrm{S}, 11^{\circ} 22^{\prime} \mathrm{E}\right)$, Scierie $\left(0^{\circ} 42^{\prime} \mathrm{N}, 13^{\circ} 05^{\prime} \mathrm{E}\right)$; Sebe $\left(0^{\circ} 45^{\prime} \mathrm{S}, 1^{\circ} 34^{\prime} \mathrm{E}\right)$; Tambi $\left(1^{\circ} 15^{\prime} \mathrm{S} ; 11^{\circ} 13^{\prime} \mathrm{E}\right) ; \quad$ Trouwaya $\left(0^{\circ} 12^{\prime} \mathrm{N}\right.$; $\left.11^{\circ} 31^{\prime} \mathrm{E}\right)$; Weliga $2\left(0^{\circ} 30^{\prime} \mathrm{S}, 10^{\circ} 12^{\prime} \mathrm{E}\right)$; Yoko $\left(0^{\circ} 2^{\prime} \mathrm{N}, 13^{\circ} 39^{\prime} \mathrm{E}\right)$, Zadouinde $\left(0^{\circ} 51^{\prime} \mathrm{N}, \quad 13^{\circ} 33^{\prime} \mathrm{E}\right), \quad$ Zambakaganga $\left(0^{\circ} 57^{\prime} \mathrm{N}, 13^{\circ} 46^{\prime} \mathrm{E}\right)$, Zolende $\left(0^{\circ} 15^{\prime} \mathrm{N}, 13^{\circ} 26^{\prime} \mathrm{E}\right)$; and Zomoko $\left(0^{\circ} 31^{\prime} \mathrm{N}, 11^{\circ} 26^{\prime} \mathrm{E}\right)$.

\section{Tick species}

\section{Amblyomma Koch, 1844}

Amblyomma compressum Macalister, 1872

This species is found almost exclusively on the three African species of pangolin: Manis temminckii, $M$. tetradactyla, and M. tricuspis. In Gabon, $A$. compressum had previously been reported in CapLopez (Neumann, 1899; as Amblyomma cuneatum), Mayumba and Libreville (Fiason, 1943; as A. cuneatum) on the three-cusped pangolin (Manis tricuspis). We found A. compressum in all regions where M. tricuspis was sampled (Guietsou, Ilendo, Koungoulé, Weliga 2, Oyem and Massaha).

\section{Amblyomma paulopunctatum Neumann, 1899}

In Gabon, this species has previously been found in Libreville and Tchibanga (1930, Collection Brumpt Institut de Parasitologie, Faculté de Médecine de Paris, CBpt) on Potamochoerus porcus bush pigs. The Suidae family is the preferred host.

\section{Amblyomma splendidum Giebel, 1877}

This species is mainly found on the African buffaloes, Syncerus caffer nanus. It was first collected in
Gabon in Cap Lopez, and later in Ngomo (Robinson, 1926), Lambaréné, Lastourville, Ndende and Tchibanga (Neumann, 1899). We collected adult and nymph stages of $A$. splendidum by sledge sampling on buffalo ponds in Lopé reserve. This species is probably widespread in Gabon, like its host species. It was occasionally found on Kobus ellipsiprymnus in the river Nyanga.

\section{Amblyomma tholloni Neumann, 1899}

This species is commonly found on elephants (Loxodonta africana). In Gabon, it has previously been found in Libreville and Tchibanga (1930, CBpt). We collected A. tholloni in Lopé from tree branches and by the sledge method. In Sebe, we also collected a male of this species from Atherurus africanus.

\section{Amblyomma variegatum Fabricius, 1794}

This species appears to have a broad range of hosts. It has previously been found by Rousselot (1953) and Moubamba (2006) in Libreville, Oyem, Mitzic, Mayumba and Franceville, on cattle and dogs (Moubamba, 2006). We found it on cattle in Franceville.

\section{Amblyomma arcanum Karsch, 1879}

This species was previously considered as Aponomma arcanum. Amblyomma arcanum feed on reptiles. It has been collected by Morel (1961) on Varanus niloticus.

\section{Dermacentor Koch, 1844}

Dermacentor circumguttattus Neumann, 1897

This species, like A. tholloni, is found on elephants. It has previously been collected in Lambaréné (1910, MHNP, Muséum Histoire Naturelle Paris) and Tchibanga (1930, CBpt).

\section{Haemaphysalis Koch, 1844}

Haemaphysalis hoodi Warburton and Nuttall, 1909

This species parasitizes birds. It has previously been found in Tchibanga on Coucal birds (Centropus sp.) (1910, MHNP) and in Lambaréné on a chicken (1910, MHNP). 
Haemaphysalis leachi Audouin, 1827

This species was first described in Cap-Lopez on Manis sp. (Neumann, 1897), then in Lambaréné on Genetta sp. (1910, MHNP) and in Mitzic on dogs (1954, IPP, Institut Pasteur Paris). The leachi group was later separated into different species (Apanaskevich et al., 2007). We found one H. laechi male on a Herpestes sanguinea in Benguie 2.

\section{Haemaphysalis paraleachi}

Camicas, Hoogstraal and El Kammah, 1983

We detected this species in Gabon for the first time. It was found only at adult stages on domestic dogs in Dienga. Interestingly, all dogs sampled were parasitized by this species, but no specimens of Rhipicephalus sanguineus were found.

\section{Haemaphysalis parmata Neumann, 1905}

In Gabon, this species was first described in Lambaréné (1910, MHNP) and then in Tchibanga (1930, CBpt) on Potamochoerus porcus. We often found it, at all stages, on wild and domestic ungulates in almost all the regions studied: Cephalophus dorsalis and Philantomba monticola in Bighoundou, Lac Nkouvié, Akon Ebe, Guietsou, Weliga 2, Koungoulé, Zomoko, Oyem, Latta, La Scierie, Massaha, Nze Vatican, Zambakaganka, Mela, Hendje, Zolende, Bakwaka on Tragelaphus spekii in Lambaréné and Oyem, on Hyemoschus aquaticus in Moukouagni and on Ovis aries and Capra hircus in Dienga.

\section{Haemaphysalis punctaleachi}

Camicas, Hoogstraal and EI Kammah, 1973

In Gabon, adult specimens of this species were found by Ellenberger in Lambaréné on Genetta genetta and on Nandinia binotata in Belinga in 1962 (Camicas J.L. et al., 1973). We also collected adult stages from Nandinia binotata in Olounga, Atherurus africanus in Guietsou, and Cephalophus dorsalis in Nkolabona and Guietsou.

\section{Ixodes Latreille, 1795}

Ixodes aulacodi Arthur, 1956

We detected this species in Gabon for the first time in Bighoundou were it was collected at adult and nymphal stage on his preferred host, the greater cane rat Thryonomys swinderianus.

\section{Ixodes cumulatimpunctatus Schulze, 1943}

This species was firstly collected in Gabon in previous studies in Tchibanga on domestic dog (Morel, 1964, CBpt). We found it on Cephalophus dorsalis and P. monticola in Hendje, Mandilou, Onkoua and Zambakaganga at adult and nymphal stage. Adult specimens were also collected on Atherurus africanus in Sebe, on Manis tricuspis in Abong awoum and on Potamochoerus porcus in Lolo 1.

Ixodes muniensis Arthur and Burrow, 1957

This species was only recorded in Libreville on Cephalophus sp. (Morel, 1964, CBpt).

Ixodes rageaui Arthur, 1957

This species was collected on Cercopithecus cephus in Mokabo (Morel, 1964, CBpt).

\section{Ixodes rasus Neumann, 1899}

Ixodes rasus is one of the tick species most frequently found on a large variety of hosts. In Gabon, it was first collected on Manis sp. in Libreville (Fiasson, 1943) on Civettictis civetta, and on Potamochoerus porcus in Tchibanga (1930, CBpt). We commonly found this species in all regions; on Atherurus africanus (adult and nymph specimens) in Massaha, Guietsou, Lalara, Mouloudou and Weliga; on Atilax paludinosus (nymphs) in Trouwaya, on Cephalophus dorsalis, C. nigrifrons, P. monticola (larvae, nymphs and adults) in Ekata, Guietsou, Hendje, Hevegab, Latta, La scierie, Massaha, Mbomo, Nkolabona, Nze Vatican, Oyem, Zambakangaka, Zolende and Zomoko; on Manis tricuspis (adults and nymphs) in Guietsou, Ilendo, Massaha, Lemenga, Oyem, Weliga; on Potamochoerus porcus (adults) in Guietsou; on Nandinia binotata (adults, nymphs) in Abong Awoum and Malolo and finally on Kinixys erosa (adult) in Nkolabona.

\section{Rhipicephalus Koch, 1844}

Rhipicephalus annulatus Say, 1821

This species was previously considered as Boophilus annulatus. $R$. annulatus feed almost exclusively on 
domestic ungulates (especially cattle) and also on African buffaloes. We detected R. annulatus for the first time in Gabon on cattle in Franceville.

\section{Rhipicephalus aurantiacus Neumann, 1907}

This species is considered to be a junior synonym of $R$. ziemanni by some authors (Guglielmone et al., 2009). This species was first found in Ngomo on cattle (Neumann, 1908; as R.cuneatus) and then in Tchibanga on Potamoechoerus porcus (1930, CBpt).

\section{Rhipicephalus cliffordi Morel, 1965}

This species is considered to be a junior synonym of R. pseudolongus by some authors (Guglielmone et al., 2009). In Gabon, adults of this species were first collected in Ndendé (Rousselot, 1953; as R. capensis and R. capensis longus). It was probably confused with Rhipicephalus pseudolongus or R. longus. R. cliffordi has been found on Potamoechoerus porcus in Tchibanga and on Syncerus caffer nanus in Ndendé (Morel, 1965a).

\section{Rhipicephalus complanatus Neumann, 1911}

This species is commonly found on wild and domestic pigs. It was first detected in Samkita, Lambarené (1913, MNHN) and Tchibanga on Potamochoerus porcus (1930, CBpt). We also collected adult stages from P. porcus in Djounou, Omoy, Yoko, Guietsou and Lambaréné.

\section{Rhipicephalus decoloratus Koch, 1844}

This species was previously considered as Boophilus decoloratus. This species was described first in Cap Lopez on Syncerus caffer nanus (Neumann, 1901) and cattle (Fiasson, 1943), and subsequently in Libreville on cattle (Minning, 1935; Rousselot, 1953). We also found it on cattle in Franceville.

\section{Rhipicephalus longus Neumann, 1907}

This species is found on various wild and domestic ungulates and other mammals. In Gabon, it was first found in Franceville on domestic pigs (1926, CBpt) and in Tchibanga on dogs (1930, CBpt).

\section{Rhipicephalus pseudolongus Santo Dias, 1953}

This species is often confused with $R$. longus. We found adult specimens of $R$. pseudolongus on cattle in Franceville.
Rhipicephalus sanguineus Latreille, 1806

This common species is mainly associated with domestic dogs. It has been collected in Libreville on dogs (Morel and Vassiliades, 1963; Moubamba, 2006). We also found it, at all stages, on domestic dogs in Franceville.

\section{Rhipicephalus simpsoni Nuttall, 1910}

We found adult $R$. simpsoni, for the first time in Gabon, on the greater cane rat Thryonomys swinderianus in Bighoundou.

\section{Rhipicephalus sulcatus Neumann, 1908}

In Gabon, this species has only been described on domestic dogs in Tchibanga, 1930 CBpt).

\section{Rhipicephalus ziemanni Neumann, 1904}

This species was first detected on cattle in Ngomo (Neumann, 1908; as R. cuneatus). We frequently found adult R. ziemmani in all regions of Gabon, on many animal species: Cephalophus dorsalis, C. callipygus, P. monticola, Hyemoschus aquaticus and Tragelaphus spekii in Doumaï, Djounou, Guidouma, Guietsou, Kassiélé, Koungoulé Massaha, Lambaréné, Ondili and Oyou; on Ovis aries in Dienga; on Potamochoerus porcus in Djounou and Omoy; on Nandinia binotata in Olounga and Moloulou; and finally on Atherurus africanus in Mandilou.

\section{CONCLUSION}

This survey identified four tick species for the first time in Gabon, namely Haemaphysalis paralaechi, Ixodes aulacodi, Rhipicephalus annulatus and Rhipicephalus simpsoni. So far, 28 species of the Ixodidae ticks have been recorded in this country. In the central African region, 53 species Ixodidae tick have been reported in Cameroun (Morel and Mouchet 1965) and 46 in the Central African Republic (Cornet 1995). It is thus highly probable that more tick species are present in Gabon, particularly those belonging to the genus Rhipicephalus, which is the most diverse group of afrotropical ticks. No ticks of the genus Hyalomma have been reported, probably because they are mainly associated with arid tropical climates. However, they might possibly be present in savannas of southern Gabon. 


\section{REFERENCES}

Apanaskevich D.A., Horak G.I., L. C.J. 2007 — Redescription of Haemaphysalis (Rhipistoma) elliptica (Koch, 1844), an old taxon of the Haemaphysalis (Rhipistoma) leachi group from East and southern Africa, and of Haemaphysalis (Rhipistoma) leachi (Audouin, 1826) (Ixodida, Ixodidae) — Onderstepoort J. Vet. Res., 74: 181208.

Arthur D.R. 1965 - Ticks of the genus Ixodes in Africa London: Athlona Press. pp. 348.

Camicas J.L., Hoogstraal H., EI Kammah M.K. 1973 Notes on African Haemaphysalis ticks . XI. H. (Rhipistoma) Punctalaechi sp. n., a parasite of West African forest carnivores (Ixodoidea: Ixodidae) - Journal parasitology, 59: 563-568. doi:10.2307/3278796

Cornet J.P. 1995 - Contribution à l'étude des tiques (Acarina : Ixodida) de la République Centrafricaine. 4. inventaire et répartition - Acarologia, 36: 203-212.

Cornet J.P., Degalier N., Hervé J.P. 1984 - Description of sledge for tick sampling (Acarina : Ixodina) - Acarologia, 25: 17-19.

Elbl A., Anastos G. 1966a - Ixodid ticks (Acarina. Ixodoidea) of central Africa: (Genus Ixodes Latreille, 1795) - Ann. Mus. Roy. Afrique Centrale, Tervueren. pp. 205.

Elbl A., Anastos G. 1966b - Ixodid ticks (Acarina. Ixodoidea) of central Africa: Genera Aponomma (Neumann, 1899), Boophilus (Curtice 1891), Dermacentor (Koch, 1844), Haemaphysalis (Koch,1844), Hyalomma (Koch,1844) and Rhipicentor (Nuttall \& Warburton,1908). - Ann. Mus. Roy. Afrique Centrale, Tervueren. pp. 412.

Elbl A., Anastos G. 1966c - Ixodid ticks (Acarina. Ixodoidea) of central Africa: General introduction, genus Amblyomma Koch,1844) -: Ann. Mus. Roy. Afrique Centrale, Tervueren. pp. 275.

Elbl A., Anastos G. 1966d - Ixodid ticks (Acarina. Ixodoidea) of central Africa: Genus Rhipicenhalus (Koch, 1844) - Ann. Mus. Roy. Afrique Centrale, Tervueren. pp. 412.

Fiasson R. 1943 - Contribution à l'étude des arthropodes vulnérants du Moyen-Congo - Rev. Sci. Méd. Pharm. Vét. Afr. Fr. Libre, 2: 257-282.

Guglielmone A.A., Robbins R.G., Apanaskevich D.A., Petney T.N., Estrada-Pena A., Horak I.G. 2009 - Comments on controversial tick (Acari: Ixodida) species names and species described or resurrected from 2003 to 2008 - Exp. Appl. Acarol., 48: 311-27. doi:10.1007/s10493-009-9246-2

Hoogstraal H. 1956 - A frican Ixodoidea. I. Ticks of the Sudan (with special reference to Equatoria Province and with preliminary reviews of the genera
Boophilus, Margaropus, and Hyalomma) - Washington, D.C.: Dept. Navy, Bur. Med. Surg. pp. 1101.

Minning W. 1935 - Zur Kenntnis des Genus Boophilus Curtice. I - Ztschr. Parasitenk, 7: 719-721. doi:10.1007/BF02121332

Morel P.C. 1965a - Description de Rhipicephalus cliffordi n. sp. d'Afrique occidentale (groupe de R. compositus; Acariens, Ixodoidea) - Rev. Elev. Méd. Vét. Pays Trop., 17: 637-654.

Morel P.C. 1965b - Les tiques d'Afrique et du bassin Méditerranéen (Ixodoidea). Distribution, Biologie, écologie, rôle pathogène - Maisons-Alfort. pp. 1342.

Morel P.C. 1969 - Contribution à la connaissance de la distribution des tiques (Acariens, Ixodidae et Amblyommidae) en Afrique éthiopienne continentale - pp. 388.

Morel P.C., Mouchet J. 1958 — Les Tiques du Cameroun (Ixodidés et Argasidés) II - Annales de Parasitologie (Paris), 33: 69-111.

Morel P.C., Mouchet J. 1965 — Les Tiques du Cameroun (Ixodidés et Argasidés) - Annales de Parasitologie (Paris), 40: 411-496.

Morel P.C., Vassiliades G. 1963 - Les Rhipicephalus du groupe sanguineus: espèces africaines (Acariens, Ixodidés) - Rev. Elev, Méd. Vét. Pays Trop., 15: 343-386.

Moubamba D. 2006 - Identification et distribution des espèces de tiques (Acari : Ixodidae) qui infestent les chiens à Libreville — Ann. Méd. Vét., 150: 193-196.

Neumann L.G. 1897 - Révision de la famille des Ixodidés. II. Rhipicephalinae - Mém. Soc. Zoologique France, 10: 324-420.

Neumann L.G. 1899 - Révision de la famille des Ixodidés. III. Ixodidae. - Mém. Soc. Zoologique France, 12: 107-294.

Neumann L.G. 1901 - Révision de la famille des Ixodides. IV. - Mém. Soc. Zoologique France, 14: 249372.

Robinson L. 1926 - The genus Amblyomma. Ticks, a monograph of the Ixodoidea - Cambridge: Univ. Press. pp. 1-302.

Rousselot R. 1953 - Notes de parasitologie II. Ixodes Paris, Vigot. pp. 135.

Walker J.B., Keirans J.B., Horak I. 2000 - The Genus Rhipicephalus (Acari, Ixodidae): A Guide to the Brown Ticks of the World - pp. 643.

Wilson D.E., Reeder D.A.M. 2005 - Mammal Species of the World. A Taxonomic and Geographic Reference Johns Hopkins University Press. pp. 2142. 


\section{COPYRIGHT}

$(\infty)_{\text {EY-NC-ND }}$ Pourrut et al.. Acarologia is under free license. This open-access article is distributed under the terms of the Creative Commons-BY-NC-ND which permits unrestricted non-commercial use, distribution, and reproduction in any medium, provided the original author and source are credited. 